since 1959 have revealed a further 216 graves mainly of seventh- and early eighth-century date. Three at least had been under small barrows surrounded by shallow ditches (Wilson and Hurst, 1966). At Eastry the whole extent of the cemetery is not visible in the air photograph; moreover, not all the marks may be of the same origin, but between two and three hundred graves may probably be distinguished, making this one of the largest cemeteries of the period known in Kent. At Finglesham the orientation of the graves varies, while at Eastry, the majority are clearly aligned east and west. Whether this is sufficient

\section{A. Newham and Stonehenge}

In the last decade the pages of ANTIQUITY have provided the main forum of debate about Stonehenge and its astronomical significance. It is fitting, therefore, to record here the death in April 1974 of one of the most active and dedicated contributors to Stonehenge studies, Mr C. A. Newham, known to his friends as Peter.

Peter Newham retired from the post of Group General Manager of the North Eastern Gas Board some fifteen years ago, and thereafter devoted his time wholeheartedly to the astronomical and metrological aspects of Stonehenge. Indeed, apart from the official custodians, probably no man has spent more time in recent years on the site itself, in spite of its inconvenient distance from his home in Yorkshire.

His ideas and observations were published mainly, and with a characteristic but unjustified modesty, in three pamphlets, the last of which I had the pleasure of reviewing in these pages (Atkinson, 1972). In these he gradually developed his views about the metrical properties of the monument and its solar and lunar alignments, the latter having been originally outlined in a newspaper article. He also contributed a paper to Nature, and took part in the ANTIQUITY symposium of comments on Hoyle's hypothesis (I966). At the same time he conducted a vigorous correspondence with many fellow-workers, of whom I am gratefully one. His publications, listed below, deserve the proof that the cemetery is of a Christian community may not be accepted by everyone, but the contrast in plans is striking. Some AngloSaxon communities may well have changed their burial places in the seventh century for reasons arising from the conversion to Christianity.

J. K. ST JOSEPH

CHADWICK, S. E. I 958. The Anglo-Saxon cemetery at Finglesham, Kent: a reconsideration, Med. Arch., II, 1-71. An appendix to this paper gives a list of early Anglo-Saxon sites in NE Kent. STEBring, W. P. D. I929. The Jutish cemetery near Finglesham, Kent, Arch. Cant., xLI, I I 5-25.

WILSON, D. M. and D. G. HURST (eds.). I 966 . Medieval Britain in 1964, Med. Arch., rx, 172; idem, 1969, XII, I 58 .

attention and the respect of every investigator of the problems of Stonehenge, present and future.

It is too early to say how many of his more speculative ideas will withstand the winnowing of time; but of his lasting contribution to Stonehenge studies there is already no doubt. $\mathrm{He}$ was the first in this country to offer a convincing explanation of the geometry of the four Stations and its relationship to the latitude of the site, even though he was, unknowingly, partially anticipated in this discovery by a couple of years (Charrière, 196r). He was the first to measure with a theodolite a comprehensive set of horizon altitudes, which he generously made available to others (Hawkins, 1966; Atkinson, 1967). He was also the first to give a detailed analysis and interpretation of the enigmatic array of postholes on the entrancecauseway of the circular earthwork; and the first again to provide an astronomical explanation of the three huge postholes found during the extension of the Stonehenge car-park in 1966. For this and for much else besides he will be remembered with affection and gratitude; and in the landscape of Stonehenge itself his memorial is Peter's Mound, a newly-discovered feature on the northeastern skyline thus named by some of his friends and collaborators, which may yet prove to be the site of a distant marker for the sunrise at the summer solstice (Thom, I974).
RICHARD ATKINSON 


\section{ANTIQUITY}

AtKInSON, R. J. C. 1967. Hoyle on Stonehenge: some comments, Antiquity, xLI, 92-5.

1972. Antiquity, XLVI, 333.

CHARRIERE, G. I961. Stonehenge: rythmes architecturaux et orientation, Bull. Soc. Préhistorique Francaise, LVIII, 276-9.

HAwkins, G. s. 1966. Astro-archaeology, Smithsonian Institution Astrophysical Observatory Special Report No. 226 (Cambridge, Mass.).

HOYLE, F. I966. Speculations on Stonehenge, Antiquity, XL, 262-76.
Newham, C. A. 1963. Yorkshire Post, I6 March. r964. The engima of Stonehenge, privately printed, John Blackburn, Leeds.

I966. Stonehenge: a neolithic 'observatory', Nature, $211,456-8$.

I967. Hoyle on Stonehenge: some comments, Antiquity, XLI, 96-7.

1970. Supplement to The enigma of Stonehenge (John Blackburn, Leeds).

1972. The astronomical significance of Stonehenge (John Blackburn, Leeds).

THOM, A. et al. 1974. Stonehenge, fournal of the History of Astronomy, v, 71-90.

\section{A jade axe from the Somerset Levels}

PLATE XXIV

This beautiful jadeite axe is published by fohn Coles, Department of Archaeology, University of Cambridge, Bryony Orme, Department of History, University of Exeter, and A. C. Bishop and A. R. Woolley, both of the Department of Mineralogy, British Museum (Natural History). The peat deposits of the Somerset Levels have yielded many prehistoric finds, including objects reported in Antiquity (Coles, 1968; Coles and Hibbert, I971). Recent archaeological excavations in the area have been concentrated upon a neolithic track of the late fourth millennium BC, the Sweet track. This was built of numerous worked wooden pieces to form a footpath of single plank width, raised above the marsh and connecting the Polden Hills and the island of Westhay in the middle of the Levels. Quantities of neolithic debris have been recovered from beside the track, discarded during the building and use of the footpath, or flooded in, including pottery, wooden artifacts and flints. These neolithic objects and the results of the first two seasons' work on the Sweet track have recently been published (Coles, Hibbert and Orme, 1973).

In July 1973, during the excavation of a further 100 metres of the track, the end of a polished stone axe was discovered protruding from beneath one of the many stray boards lying beside the track (PL XxIva). When the board was lifted, a complete and perfect pale green axe was revealed (PL. xxrvb and FIG. I). It has subsequently been identified in the British Museum (Natural History) as jadeite. It is undamaged, its context is known and well-dated, and it is reliably associated with a wealth of neolithic material. The axe, which is beautiful by any standards, is an important addition to the slowly increasing inventory of neolithic material culture, and it may throw light upon the place of jadeite axes in neolithic society.

The axe measures $203 \mathrm{~mm}$. by $64 \mathrm{~mm}$. by $22 \mathrm{~mm}$., and its weight is $403.56 \mathrm{~g}$.; its specific gravity of 3.35 is commensurate with jadeite. The implement is smooth and highly polished over the whole of its surface, and has an unblemished cutting edge. It is almost perfectly symmetrical and would appear to be unused. The axe is a grey-blue to pale green colour, best described as glaucous, or greenish glaucous (Ridgway, 1912). It has a rough, but distinctive, foliation and a light-coloured band runs obliquely across one face of the axe. At the butt end the axe is a beautiful translucent pale green colour.

There are two principal mineralogical constituents: a pale green hard mineral which grades into a softer white variety giving a marbled appearance to much of the surface. $\mathrm{X}$-ray powder photographs of both the green and white material gave a jadeite pattern. The second mineral occurs as isolated grains amongst the jadeite. The grains are yellowbrown and some have weathered out leaving pits. An X-ray powder photograph of this material gave a rutile pattern. Rutile is the commonest of the polymorphs of titanium dioxide $\left(\mathrm{TiO}_{2}\right)$.

A petrographic examination of the axe has 